\title{
EVALUATION OF SUPPLY CHAIN ANALYTICS WITH AN INTEGRATED FUZZY MCDM APPROACH
}

\author{
Gülçin BÜYÜKÖZKAN ${ }^{1}$, Merve GÜLER ${ }^{2}$, Esin MUKUL ${ }^{3}$, Fethullah GÖÇER ${ }^{4}$
}

\begin{abstract}
Recently, the popularity of big data and business analytics has increased with advanced technological developments. Supply chain analytics (SCA) notion was born with the implementation of these technologies in supply chains that become more global, more complex, more extended, and more connected each day. SCA aims to find meaningful patterns in supply chain processes with the application of statistics, mathematics, machine-learning techniques, and predictive modeling. In this context, companies try to find ways to create business value for their supply chains by leveraging SCA. However, the selection of the most appropriate SCA tool is a complicated process that contains many influencing factors. For instance, the graphical and intuitive features, the data extraction method and real-time operability can be the influencing factors for such a selection. Therefore, in this study, it is aimed to provide an integrated technique for prioritizing SCA success factors and for evaluating SCA tools. For addressing these problems, fuzzy logic and multi-criteria decision making (MCDM) techniques are used. An integrated fuzzy simple additive weighting (SAW) - a technique for order preference by similarity to ideal solution (TOPSIS) approach is applied. The weights of the success factors are calculated by using fuzzy SAW technique, and the SCA tools are evaluated by using fuzzy TOPSIS technique. The success factors and the SCA tool alternatives are determined by reviewing the literature and industry reports, and by collecting experts' opinions. An application is given to illustrate the potential of the proposed approach. At the end of the study, the suggestions for future studies are presented.
\end{abstract}

Keywords: fuzzy logic, MCDM, SAW, success factors, supply chain analytics, TOPSIS

JEL Codes: L86, O14, O33

\section{ENTEGRE BULANIK ÇKKV YAKLAŞIMIYLA TEDARİK ZINCİRİ ANALITTIĞİNIN DEĞERLENDİRILMESI}

\section{$\ddot{O} \mathbf{z}$}

Son zamanlarda, teknolojideki hızlı ve çarpıcı gelişmelerle birlikte büyük veri ve iş analitiğinin popülerliği artmıştır. Tedarik zinciri analitiği (TZA) kavramı, dijital teknolojilerin her geçen gün daha küresel, daha karmaşık, daha kapsamlı ve daha bağlantılı hale gelen tedarik zincirlerinde uygulanması ile ortaya çıkmıştır. TZA, istatistik, matematik, makine öğrenme teknikleri ve öngörücü modelleme uygulamasıyla tedarik zinciri süreçlerinde çıkarım yapmayı amaçlamaktadır. Bu bağlamda, şirketler tedarik zincirleri için TZA'yı kullanarak işlerine değer yaratmanın yollarını bulmaya çalışmaktadır.

\footnotetext{
1 Prof. Dr. Gülçin Büyüközkan, Galatasaray University, Faculty of Engineering and Technology, Department of Industrial Engineering, İstanbul, Turkey, gbuyukozkan@gsu.edu.tr ORCID: 0000-00022112-3574.

2 Research Asst. Merve Güler, Galatasaray University, Faculty of Engineering and Technology, Department of Industrial Engineering, İstanbul, Turkey, mguler@gsu.edu.tr ORCID: 0000-0003-16641139.

3 Research Asst. Esin Mukul, Galatasaray University, Faculty of Engineering and Technology, Department of Industrial Engineering, İstanbul, Turkey, emukul@gsu.edu.tr ORCID: 0000-0003-48358821.

4 Asst. Prof. Fethullah Göçer, Kahramanmaraş Sütçü İmam University, Faculty of Engineering and Architecture, Department of Industrial Engineering, Kahramanmaraş, Turkey, gocer.fethullah@gmail.com ORCID: 0000-0001-9381-4166.
} 
Ancak, en uygun TZA aracının seçimi, kararı etkileyen birçok faktör içeren karmaşık bir süreçtir. Örneğin, grafiksel ve sezgisel özellikler, veri çıkarma yöntemi ve gerçek zamanlı çalışabilirlik, bu seçimi etkileyen faktörler olabilir. Bu nedenle, bu çalıșmada, TZA başarı faktörlerini belirlemek ve TZA araçlarını değerlendirmek için entegre bir teknik sunmak amaçlanmıştır. Bu problemin çözümü için bulanık mantık ve çok kriterli karar verme (ÇKKV) teknikleri kullanılmıştır. Entegre bulanık basit toplamlı ağırlıklandırma (SAW) - TOPSIS yaklaşımı uygulanmıştır. Başarı faktörlerinin ağırlıkları bulanık SAW tekniği kullanılarak hesaplanmış ve TZA araçları bulanık TOPSIS tekniği ile değerlendirilerek sıralanmıştır. Başarı faktörleri ve TZA aracı alternatifleri akademik yazın ve endüstri raporları gözden geçirilerek belirlenmiş ve uzmanların görüşleri ile finalize edilmiştir. Önerilen yaklaşımın potansiyelini göstermek için bir uygulama gerçekleştirilmiş; çalışmanın sonunda ise gelecek çalışmalar için öneriler sunulmuştur.

Anahtar Kelimeler: Bulanık mantık, ÇKKV, SAW, tedarik zinciri analitiği, tedarik zinciri analitiği başarı faktörleri, TOPSIS.

JEL Kodları: L86, O14, O33

\section{Introduction}

The complex, extended, connected, and global supply chains produce a considerable amount of data over various phases. Companies have to manage this data for executing their daily works. Big data and business analytics have emerged as a critical business capability with the widespread use of digital technologies (Wang et al., 2016). Big data analytics give promise in business transformation by capturing both practitioners and researchers' attention, especially in the marketing and finance sectors. On the other hand, there is an expectation about the benefits of big data analytics utilization in supply chain management (Rozados and Tiahjano, 2014).

The utilization of big data analytics in supply chain management is defined as supply chain analytics (SCA) (Wang et al., 2016). It allows informed decision-making to companies by giving insight from their data. SCA can be defined as the utilization of quantitative methods for deriving insights from data in order to obtain a more profound comprehension. It aims to increase the visibility, collaboration and integration in supply chains to solve the supply chain problems (e.g., inefficiencies and wastages in the chains, delayed shipments, rising fuel costs, inconsistent suppliers) (Arya et al. ,2017; Barnaghi et al., 2013).

Companies gain a competitive advantage with the utilization of SCA. Moreover, many profits can be provided as the integration of global supply chains and logistics processes, the improvement of the visibility, flexibility, the management of demand volatility, and the handling of cost fluctuations. In the strategic decisions on supply chain management, SCA can help companies to make strategic decisions on sourcing, network design, product design, and product development. In the operational decisions on supply chain management, SCA can assist management in making decisions about supply chain operations (i.e., demand planning, procurement, production, inventory, and logistics) (Wang et al., 2016).

Various types of SCA tool exist in the market. The selection of the most appropriate SCA tool is crucial for companies. Therefore, in this study, the aim is to present a research methodology that employs MCDM methods for selecting the most appropriate SCA tool. 
The literature and industry reports are reviewed, and experts' opinions are collected to construct the selection model. The research methodology is based on the integration of fuzzy multi-criteria decision-making (MCDM) techniques. To overcome the uncertainty in the decision-making, fuzzy logic proposed by Zadeh (1965) is utilized. The importance degrees of the success factors are calculated using the Simple Additive Weighting (SAW) method. The Technique for Order Preference by Similarity to Ideal Solution (TOPSIS) approach is applied to evaluate SCA.

This study is organized as follows. In the following section, the literature review is provided. Then, the research methodology is presented in detail. An application is given to illustrate the potential of the proposed approach. At the end of the study, the suggestions for future studies are provided.

\section{Literature Review}

Recently, several papers have been dedicated to investigating the SCA subject. These papers are examined in detail in Table 1. According to Wang et al. (2016), current papers on SCA have mainly focused on analyzing definitions and different perspectives or identifying opportunities, however, the SCA subject is still in its infancy.

Table 1. The literature review for papers about SCA subject

\begin{tabular}{|c|c|c|c|}
\hline Year & Author(s) & Aim of the Paper & $\begin{array}{l}\text { Type of the } \\
\text { Paper }\end{array}$ \\
\hline 2010 & Trkman et al. & $\begin{array}{l}\text { To investigate the relationship between analytical } \\
\text { capabilities in the supply chain and its } \\
\text { performance }\end{array}$ & Research Paper \\
\hline 2014 & Chae et al. & To define the architecture of SCA & Review Paper \\
\hline 2014 & $\begin{array}{l}\text { Rozados and } \\
\text { Tjahjono }\end{array}$ & $\begin{array}{l}\text { To investigate the fundamentals of big data } \\
\text { analytics and its taxonomy in supply chain } \\
\text { management }\end{array}$ & Review Paper \\
\hline 2014 & Souza & $\begin{array}{l}\text { To describe the application of advanced analytics } \\
\text { techniques to supply chain management }\end{array}$ & Research Paper \\
\hline 2016 & Biswas et al. & $\begin{array}{l}\text { To propose a Big Data-centric architecture for } \\
\text { supply chain management exploiting the current } \\
\text { state }\end{array}$ & Research Paper \\
\hline 2016 & Wang et al. & $\begin{array}{l}\text { To review the SCA literature and to propose an } \\
\text { SCA maturity framework }\end{array}$ & Review Paper \\
\hline 2017 & Arya et al. & $\begin{array}{l}\text { To explore the use of big data analytics in the } \\
\text { supply chain of the army }\end{array}$ & Review Paper \\
\hline 2017 & Barbosa et al. & $\begin{array}{l}\text { To identify the most central actors of SCA in terms } \\
\text { of supply chain management research streams }\end{array}$ & Review Paper \\
\hline
\end{tabular}




\begin{tabular}{|c|c|c|c|}
\hline Year & Author(s) & Aim of the Paper & $\begin{array}{l}\text { Type of the } \\
\text { Paper }\end{array}$ \\
\hline 2017 & Engel et al. & $\begin{array}{l}\text { To investigate the challenges, benefits, and factors } \\
\text { for the introduction of SCA }\end{array}$ & Research Paper \\
\hline 2017 & Vidgen et al. & $\begin{array}{l}\text { To present a business analytics ecosystem for } \\
\text { companies }\end{array}$ & Research Paper \\
\hline 2017 & Taghikhah & $\begin{array}{l}\text { To review and illuminate the role of business } \\
\text { analytics in supply chains }\end{array}$ & Review Paper \\
\hline 2018 & $\begin{array}{l}\text { Arunachalam } \\
\text { et al. }\end{array}$ & $\begin{array}{l}\text { To review the papers examining big data analytics } \\
\text { capabilities in the context of supply chain }\end{array}$ & Review Paper \\
\hline 2018 & Barbosa et al. & $\begin{array}{l}\text { To investigate how big data analytics has been } \\
\text { studied on supply chain management studies }\end{array}$ & Review Paper \\
\hline 2018 & Hoehle et al. & $\begin{array}{l}\text { To examine the use of mobile technologies } \\
\text { facilitating customers' shopping }\end{array}$ & Research Paper \\
\hline 2018 & $\begin{array}{l}\text { Lamba and } \\
\text { Singh }\end{array}$ & $\begin{array}{l}\text { To identify the enablers of big data analytics in the } \\
\text { context of supply chain management }\end{array}$ & Research Paper \\
\hline 2018 & Tiwari et al. & $\begin{array}{l}\text { To investigate significant data analytics research } \\
\text { and application in supply chain management }\end{array}$ & Research Paper \\
\hline 2019 & Gupta et al. & $\begin{array}{l}\text { To examine the relationship between the smart } \\
\text { supply chain and information system flexibility }\end{array}$ & Research Paper \\
\hline 2019 & Ivanov et al. & $\begin{array}{l}\text { To investigate the effects of digital technology on } \\
\text { supply chain risk analytics }\end{array}$ & Research Paper \\
\hline 2019 & Kamble et al. & To review the data-driven agriculture supply chain & Review Paper \\
\hline
\end{tabular}

Some of the review papers listed in Table 1 target defining the architecture of the subject and describing the SCA taxonomy (Chae et al., 2014; Rozados and Tjahjono, 2014). It is also seen from Table 1 that the utilization of big data analytics in SCM is investigated in some of the papers (Rozados and Tjahjono, 2014; Arya et al. 2017; Arunachalam et al., 2018; Barbosa et al., 2018). Moreover, the papers about business analytics utilization in SCM and about the datadriven supply chains are examined by several authors (Taghikhah, 2017; Kamble et al., 2019).

In general, the research papers listed in Table 1 aim to define the different parts of the SCA subject (Trkman et al., 2010; Souza, 2014; Biswas et al., 2016; Vidgen et al., 2017) while some of the papers investigates the challenges, the benefits and the enablers of the SCA (Engel et al, 2017; Lamba and Singh, 2018). On the other hand, the customer size is taken into consideration in one of the papers (Hoehle et al., 2018).

It is important to note that, just one of the papers in Table 1 integrated SCA subject with MCDM methods (Lamba and Singh, 2018). Lamba and Singh (2018) used DEMATEL method to analyze and to identify the interactions between the enablers of big data analytics in the SCM context. 
In fact, for solving some problems on SCA subject, MCDM tool integration is appropriate. Therefore, in this study, we aim to fill this research gap by employing MCDM methods for the most appropriate SCA tool selection.

\section{Proposed Research Methodology}

In this paper, the proposed research methodology consists of three main phases:

Phase 1. Construction of the SCA evaluation model by determining SCA success factors and SCA tool alternatives.

Phase 2. Calculation of the success factors weights with the fuzzy SAW method.

Phase 3. Evaluation of SCA tools by fuzzy TOPSIS method according to the success factors.

\section{SCA Evaluation Model}

To construct the SCA evaluation model, the academic papers and industry reports are examined. Then, the professional opinions of the experts are collected to obtain the model's final version. The success factors for SCA tool selection are provided in Table 2, and the SCA tool alternatives are illustrated in Figure 1.

Table 2. The SCA success factors

\begin{tabular}{|c|c|c|}
\hline Fj & Success Factors & References \\
\hline F1 & Effective communication & Kumar et al. (2015), Vidgen et al. \\
& Top management support & Lamba and Singh (2018) \\
\hline F2 & Modern technology utilization & Kumar et al. (2015), Vidgen et al. \\
\hline F3 & Logistics synchronization & Ngai et al. (2004) \\
\hline F4 & Data security & (2018) \\
\hline F5 & Ngai et al. (2004), Lamba and Singh \\
\hline F6 & Supply chain management strategy & Kumar et al. (2015), Ngai et al. \\
& & (2004) \\
\hline F7 & Hardware and software reliability & Kumar et al. (2015), Ngai et al. \\
& & (2004) \\
\hline
\end{tabular}




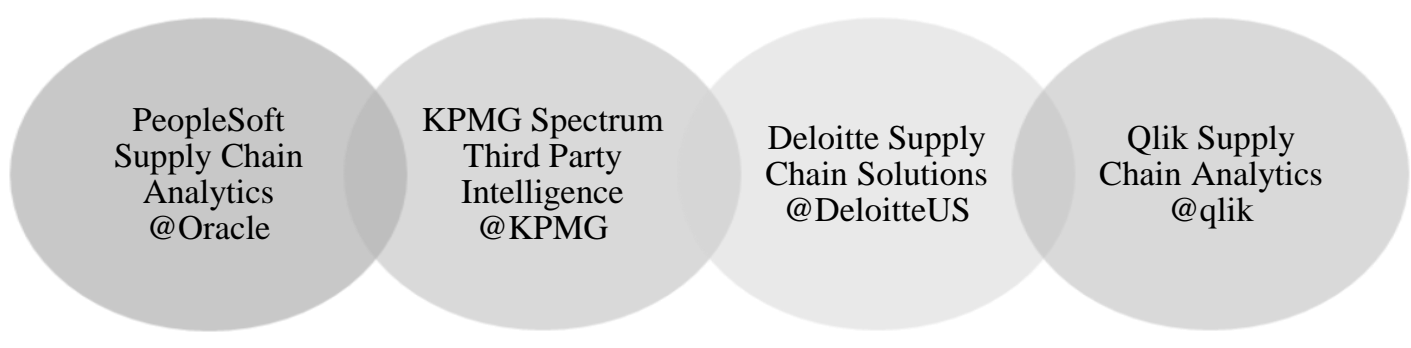

Figure 1. The SCA tool alternatives (Pontius, 2019)

\section{Fuzzy SAW Method}

In the literature, the fuzzy SAW method is proposed for facility location selection by Chou et al. (2008). The consecutive steps of this technique are explained next (Chou et al., 2008):

Step 1. DMs assess the evaluation criteria by utilizing the linguistic terms provided in Table 3.

Table 3. Linguistic terms sets used in fuzzy SAW technique (Chou et al., 2008)

\begin{tabular}{|c|c|c|}
\hline Linguistic term & Abb. & Fuzzy Numbers \\
\hline Very High & VH & $(7,10,10,10)$ \\
\hline High & H & $(5,7,7,10)$ \\
\hline Medium & M & $(2,5,5,8)$ \\
\hline Low & L & $(0,3,3,5)$ \\
\hline Very Low & VL & $(0,0,0,3)$ \\
\hline
\end{tabular}

Step 2. The matrix that consists of linguistic assessments of criteria is changed into fuzzy numbers provided in Table 3.

Step 3. The weights of DMs are not equal, and $I_{t}$ denotes importance degrees of each DM, with $0 \leq I_{t} \leq 1, t=1,2, \ldots, k$, and $\sum_{t=1}^{k} I_{t}=1$. The DMs' fuzzy weights are denoted as $\widetilde{\omega_{t}}$. The importance degrees of DMs $\left(I_{t}\right)$ is calculated as:

$$
I_{t}=\frac{d\left(\widetilde{w_{t}}\right)}{\sum_{t=1}^{k} d\left(\widetilde{w_{t}}\right)}, t=1,2, \ldots, k
$$

Here, $d\left(\widetilde{w_{t}}\right)$ denotes the defuzzified value of the fuzzy weight.

Step 4. Aggregated fuzzy weights of $C_{j}, \widetilde{W}_{J}=\left(a_{j}, b_{j}, c_{j}, d_{j}\right)$, are computed as:

$$
\widetilde{W_{J}}=\left(I_{1} \otimes \widetilde{W_{J 1}}\right) \oplus\left(I_{2} \otimes \widetilde{W_{J 2}}\right) \oplus \ldots \oplus\left(I_{k} \otimes \widetilde{W_{k 1}}\right)
$$

Here, $a_{j}=\sum_{t=1}^{k} I_{t} a_{j t}, b_{j}=\sum_{t=1}^{k} I_{t} b_{j t}, c_{j}=\sum_{t=1}^{k} I_{t} c_{j t}, d_{j}=\sum_{t=1}^{k} I_{t} d_{j t}$. 
Step 5. The fuzzy weights are defuzzified. The defuzzified $\widetilde{W}_{J}$, shown as $d\left(\widetilde{W_{J}}\right)$, is calculated as:

$$
d\left(\widetilde{W_{J}}\right)=\frac{1}{4}\left(a_{j}+b_{j}+c_{j}+d_{j}\right), j=1,2, \ldots, n
$$

Step 6. Normalized weights of $C_{j}$, shown as $W_{j}$, is computed as:

$$
W_{j}=\frac{d\left(\widetilde{w_{J}}\right)}{\sum_{j=1}^{n} d\left(\widetilde{w_{J}}\right)}, j=1,2, \ldots, n
$$

$\sum_{j=1}^{n} W_{j}=1$. Finally, the weight vector $W=\left(W_{1}, W_{2}, \ldots, W_{n}\right)$ is established.

\section{Fuzzy TOPSIS Method}

Fuzzy TOPSIS method used in this paper is adapted from Chen and Chen (2010). The consecutive steps of this technique are explained next (Büyüközkan and Çifçi, 2012):

Step 1. DMs assess alternatives by utilizing the linguistic terms provided in Table 4 to construct the decision matrix. In Table 4, the linguistic terms are associated with trapezoidal fuzzy numbers. For example, an assessment as "Very Good" is transformed to " $(7,10,10,10)$ " as fuzzy number. Then, these numbers are used in the computational steps of the methodology.

Table 4. Linguistic terms sets used in fuzzy TOPSIS technique (Chou et al., 2008)

\begin{tabular}{|c|c|c|}
\hline Linguistic term & Abb. & Fuzzy Numbers \\
\hline Very Good & VG & $(7,10,10,10)$ \\
\hline Good & G & $(5,7,7,10)$ \\
\hline Fair & F & $(2,5,5,8)$ \\
\hline Poor & P & $(0,3,3,5)$ \\
\hline Very Poor & VP & $(0,0,0,3)$ \\
\hline
\end{tabular}

Step 2. The decision matrix is normalized as:

$$
\begin{aligned}
\tilde{R} & =\left[\tilde{r}_{i j}\right]_{m . n}, i=1,2, \ldots, m ; j=1,2, \ldots n \\
\tilde{r}_{i j} & =\left(\frac{a_{i j}}{c_{j}^{+}}, \frac{b_{i j}}{C_{j}^{+}}, \frac{c_{i j}}{C_{j}^{+}}\right)
\end{aligned}
$$

where $C_{j}^{+}=\max _{i} C_{i j}$.

Step 3. The weighted normalized matrix is calculated as:

$$
\tilde{v}_{i j}=\tilde{r}_{i j} \otimes \widetilde{w}_{j}
$$

Step 4. The distances from the positive and the negative ideal solutions are calculated as:

$$
\begin{aligned}
& d_{i}^{*}=\sum_{j=1}^{n} d\left(\tilde{v}_{i j}, \tilde{v}_{j}^{*}\right), i=1,2, \ldots m ; \mathrm{j}=1,2, \ldots \mathrm{n} \\
& d_{i}^{-}=\sum_{j=1}^{n} d\left(\tilde{v}_{i j}, \tilde{v}_{j}^{-}\right), i=1,2, \ldots m ; j=1,2, \ldots n
\end{aligned}
$$


where

$$
\begin{aligned}
& A^{*}=\left\{\mathrm{v}_{1}^{*}, \mathrm{v}_{2}^{*}, \ldots, \mathrm{v}_{\mathrm{n}}^{*}\right\} \\
& A^{-}=\left\{\mathrm{v}_{1}^{-}, \mathrm{v}_{2}^{-}, \ldots, \mathrm{v}_{\mathrm{n}}^{-}\right\} \\
& d(\tilde{A}, \tilde{B})=\sqrt{\frac{1}{4} \sum_{i=1}^{n}\left|x_{i}-y_{i}\right|^{2}}
\end{aligned}
$$

Step 5. The relative distance to the ideal solution is calculated as:

$$
\mathrm{C}_{\mathrm{i}}=\frac{\mathrm{d}_{\mathrm{i}}^{-}}{\mathrm{d}_{\mathrm{i}}^{*}+\mathrm{d}_{\mathrm{i}}^{\overline{2}}}
$$

Step 6. Alternatives are ranked based on their relative closeness indices in increasing order.

\section{Application Of The Proposed Methodology}

The proposed research methodology will be applied to a logistics company. For privacy concerns, the name of the company is denoted as "XYZ." The company wants to implement SCA for various reasons (e.g., replenishment planning, real-time information, cost optimization, improved responsiveness).

$\mathrm{XYZ}$ conducts research where the managers of the company suggested to use analytical techniques. In this context, an integrated fuzzy SAW- fuzzy TOPSIS methodology is used to select the most appropriate SCA tool for the benefit of the company.

\section{Phase 1. Sca Evaluation Model Construction}

SCA success factors are:

$$
\begin{array}{lll}
\text { - } & \text { F1 } & \text { Effective communication } \\
\text { - } & \text { F2 } & \text { Top management support } \\
\text { - } & \text { F3 } & \text { Modern technology utilization } \\
\text { - } & \text { F4 } & \text { Logistics synchronization } \\
\text { - } & \text { F5 } & \text { Data security } \\
\text { - } & \text { F6 } & \text { Supply chain management strategy development } \\
\text { - } & \text { F8 } & \text { Hardware and software reliability } \\
\end{array}
$$

SCA tool alternatives are:
- A1 PeopleSoft Supply Chain Analytics @ Oracle
- $\quad$ A2 KPMG Spectrum Third Party Intelligence @ KPMG
- $\quad$ A3 Deloitte Supply Chain Solutions @ DeloitteUS
- $\quad$ A4 Qlik Supply Chain Analytics @ qlik 


\section{Phase 2. Calculation of the Success Factors' Weights by using Fuzzy SAW}

Experts evaluated the success factors by using the linguistic expressions provided in Table 2. The experts are the finance general manager, logistics manager, technology manager and technology expert of the company. They have insights about analytics projects and they have experience in supply logistics processes and logistics operations. Table 5 shows the experts' evaluations for the success factors.

(1) - (4) are employed to calculate the criteria weights. Table 6 shows the criteria weights. At the end of the fuzzy SAW method, the most critical success factor is found as effective communication with the second important one as the hardware and software reliability.

Table 5. Experts' evaluations for the success factors

\begin{tabular}{|l|l|l|l|l|}
\hline Fj & DM1 & DM2 & DM3 & DM4 \\
\hline F1 & VH & VH & VH & M \\
\hline F2 & H & H & H & H \\
\hline F3 & M & VH & M & L \\
\hline F4 & VH & H & M & M \\
\hline F5 & H & M & H & VH \\
\hline F6 & M & M & L & H \\
\hline F7 & VH & H & VH & M \\
\hline F8 & M & L & L & H \\
\hline
\end{tabular}

Table 6. Success factors' weights

\begin{tabular}{|l|l|l|l|l|l|l|l|l|}
\hline Fj & F1 & F2 & F3 & F4 & F5 & F6 & F7 & F8 \\
\hline Weights & 0.158 & 0.140 & 0.106 & 0.128 & 0.139 & 0.096 & 0.148 & 0.086 \\
\hline Ranking & 1 & 3 & 6 & 5 & 4 & 7 & 2 & 8 \\
\hline
\end{tabular}

\section{Phase 3. Ranking of the Alternatives by using Fuzzy TOPSIS}

Experts evaluated the alternatives regarding the success factors by using the linguistic expressions provided in Table 3. Table 7 shows the experts' evaluations for the alternatives.

Table 7. DM1's evaluations for the alternatives

\begin{tabular}{|l|l|l|l|l|l|l|l|l|}
\hline & F1 & F2 & F3 & F4 & F5 & F6 & F7 & F8 \\
\hline A1 & VG & G & F & VG & G & G & VG & G \\
\hline A2 & G & VG & P & G & F & VG & G & VG \\
\hline A3 & F & G & G & F & P & G & F & VG \\
\hline A4 & G & F & G & G & G & F & G & F \\
\hline
\end{tabular}


(5) - (13) are employed to rank the alternatives. Table 8 provides the result of the fuzzy TOPSIS method.

Table 8. The ranking of the alternatives

\begin{tabular}{|l|l|l|l|l|}
\hline $\mathrm{Ai}$ & $\mathrm{A} 1$ & $\mathrm{~A} 2$ & $\mathrm{~A} 3$ & $\mathrm{~A} 4$ \\
\hline $\mathrm{C}_{\mathrm{i}}$ & 0.084 & 0.102 & 0.092 & 0.082 \\
\hline Ranking & 3 & 1 & 2 & 4 \\
\hline
\end{tabular}

At the end of fuzzy TOPSIS method, the most appropriate SCA tool for XYZ is found as KPMG Spectrum Third Party Intelligence (A2).

\section{Conclusion and Perspectives}

SCA has been raised as a solution for many companies in terms of visibility, collaboration, and integration in the supply chains. In this context, SCA tool selection is one of those issues that need to be addressed. The purpose of this study was to present a research methodology for selecting the most appropriate SCA tool.

In this context, firstly, a new SCA evaluation model, is proposed. Eight success factors and four alternatives are determined with the help of literature, industry reports, and experts. Then, fuzzy SAW- fuzzy TOPSIS methodology is employed. The fuzzy SAW method is used for the weight calculation while the fuzzy TOPSIS method is used for the ranking of the alternatives. Fuzzy logic is preferred to represent the evaluations of the experts in decision-making better. Finally, an application for a company in the logistics sector is realized to illustrate the applicability of the research methodology.

In future research, it would be interesting to construct a more comprehensive evaluation model by increasing the number of factors and alternatives. For instance, a hierarchical model can be constructed for the success factors. Moreover, the robustness of the research methodology can be tested by applying other fuzzy MCDM techniques.

\section{Acknowledgment}

The authors would like to kindly thank to the experts who have contributed to this study. This study is financially supported by the Galatasaray University Research Fund.

\section{References}

Arunachalam, D., Kumar, N., \& Kawalek, J. P. (2018). Understanding big data analytics capabilities in supply chain management: Unravelling the issues, challenges, and implications for practice. Transportation Research Part E: Logistics and Transportation Review, 114, 416-436.

Arya, V., Sharma, P., Singh, A., \& De Silva, P. T. M. (2017). An exploratory study on supply chain analytics applied to spare parts supply chain. Benchmarking: An International Journal, 24(6), 1571-1580.

Barbosa, M. W., Ladeira, M. B., \& de la Calle Vicente, A. (2017). An analysis of international coauthorship networks in the supply chain analytics research area. Scientometrics, 111(3), 1703-1731. 
Barbosa, M. W., Ladeira, M. B., \& de la Calle Vicente, A. (2017). An analysis of international coauthorship networks in the supply chain analytics research area. Scientometrics, 111(3), 1703-1731.

Barnaghi, P., Sheth, A., \& Henson, C. (2013). From data to actionable knowledge: big data challenges in the web of things. IEEE Intelligent Systems, (6), 6-11.

Biswas, S., \& Sen, J. (2017). A proposed architecture for big data driven supply chain analytics. arXiv preprint arXiv:1705.04958.

Büyüközkan, G., \& Çifçi, G. (2012). A novel hybrid MCDM approach based on fuzzy DEMATEL, fuzzy ANP and fuzzy TOPSIS to evaluate green suppliers. Expert Systems with Applications, 39(3), 3000-3011.

Chae, B., Olson, D., \& Sheu, C. (2014). The impact of supply chain analytics on operational performance: a resource-based view. International Journal of Production Research, 52(16), 4695-4710.

Chen, J. K., \& Chen, I. S. (2010). Using a novel conjunctive MCDM approach based on DEMATEL, fuzzy ANP, and TOPSIS as an innovation support system for Taiwanese higher education. Expert Systems with Applications, 37(3), 1981-1990.

Chou, S. Y., Chang, Y. H., \& Shen, C. Y. (2008). A fuzzy simple additive weighting system under group decision-making for facility location selection with objective/subjective attributes. European Journal of Operational Research, 189(1), 132-145.

Engel, T., Meier, N., \& Möller, T. (2017). Proposing A Supply Chain Analytics Reference Model As Performance Enabler.

Gupta, S., Drave, V. A., Bag, S., \& Luo, Z. (2019). Leveraging smart supply chain and information system agility for supply chain flexibility. Information Systems Frontiers, 21(3), 547-564.

Hoehle, H., Aloysius, J. A., Chan, F., \& Venkatesh, V. (2018). Customers' tolerance for validation in omnichannel retail stores: Enabling logistics and supply chain analytics. The International Journal of Logistics Management, 29(2), 704-722.

Ivanov, D., Dolgui, A., \& Sokolov, B. (2019). The impact of digital technology and Industry 4.0 on the ripple effect and supply chain risk analytics. International Journal of Production Research, 57(3), 829-846.

Kamble, S. S., Gunasekaran, A., \& Gawankar, S. A. (2019). Achieving sustainable performance in a data-driven agriculture supply chain: A review for research and applications. International Journal of Production Economics.

Kumar, R., Singh, R. K., \& Shankar, R. (2015). Critical success factors for implementation of supply chain management in Indian small and medium enterprises and their impact on performance. IIMB Management review, 27(2), 92-104.

Lamba, K., \& Singh, S. P. (2018). Modeling big data enablers for operations and supply chain management. The International Journal of Logistics Management, 29(2), 629-658.

Ngai, E. W. T., Cheng, T. C. E., \& Ho, S. S. M. (2004). Critical success factors of web-based supply-chain management systems: an exploratory study. Production Planning \& Control, 15(6), 622-630.

Pontius, N. Top Supply Chain Analytics: 50 Useful Software Solutions and Data Analysis Tools to Gain Valuable Supply Chain Insights, <https://www.camcode.com/asset-tags/topsupply-chain-analytics/>, Accessed in.: July 30, 2019.

Rozados, I. V., \& Tjahjono, B. (2014, December). Big data analytics in supply chain management: Trends and related research. In 6th International Conference on Operations and Supply Chain Management, Bali.

Souza, G. C. (2014). Supply chain analytics. Business Horizons, 57(5), 595-605.

Taghikhah, F., Daniel, J., \& Mooney, G. (2017, January). Sustainable Supply Chain Analytics: Grand Challenges and Future Opportunities. In PACIS (p. 44). 
Tiwari, S., Wee, H. M., \& Daryanto, Y. (2018). Big data analytics in supply chain management between 2010 and 2016: Insights to industries. Computers \& Industrial Engineering, 115, 319-330.

Trkman, P., McCormack, K., De Oliveira, M. P. V., \& Ladeira, M. B. (2010). The impact of business analytics on supply chain performance. Decision Support Systems, 49(3), 318-327.

Vidgen, R., Shaw, S., \& Grant, D. B. (2017). Management challenges in creating value from business analytics. European Journal of Operational Research, 261(2), 626-639.

Wang, G., Gunasekaran, A., Ngai, E. W., \& Papadopoulos, T. (2016). Big data analytics in logistics and supply chain management: Certain investigations for research and applications. International Journal of Production Economics, 176, 98-110.

Zadeh, L. A. (1965). Fuzzy sets. Information and control, 8(3), 338-353. 